\title{
EFFECT OF PROBIOTIC ON INNATE IMMUNE RESPONSE IN THE LIVER OF MUS MUSCULUS BALB/C
}

\author{
Alpha Fardah Athiyyah ${ }^{1 *}$, Andy Darma ${ }^{1}$, Reza Gunadi Ranuh ${ }^{1}$, Ari Setyawati ${ }^{1}$, Bagus \\ Setyoboedi', Anang Endaryanto ${ }^{1}$, Sjamsul Arief ${ }^{1}$, Subijanto Marto Sudarmo ${ }^{1}$ \\ ${ }^{1}$ Department of Child Health, Dr. Soetomo Hospital, Faculty of Medicine, Universitas Airlangga, \\ Surabaya, Indonesia \\ *alpha-f-a@fk.unair.ac.id \\ https://doi.org/10.34302/crpjifst/2019.11.5.5 \\ Article history: \\ Received: \\ 9 March 2019 \\ Accepted: \\ 20 September 2019 \\ Keywords: \\ Probiotic; \\ Liver; \\ Innate Immune Response; \\ Kupffer cell; \\ $N F-\kappa B$;

\section{ABSTRACT} \\ Microflora in the gastrointestinal tract plays an important role in the \\ hepatocyte function from the gut-liver axis. However, the effect of probiotic \\ in innate immune response especially in Kupffer cells is still unclear. This \\ study aimed to examine the effect of probiotic on the innate immune \\ response in the liver. This study is a randomized posttest-only control group \\ experimental animal study using white mice (Mus musculus BALB/c). The \\ inclusion criteria are 10-12 weeks old, male, and weighing 30-40 mg. \\ Samples were randomized and divided into two groups: probiotic and \\ placebo. The probiotic group was given multispecies probiotic. Probiotic \\ and placebo were administrated for 21 days via a gastric tube. On day 22, \\ necropsy was performed, and liver was obtained for immunohistochemical \\ examination at the Laboratory of Biochemistry, University of Brawijaya, \\ Malang. Number of Kupffer cells and cells which expressing NF- $\mathrm{B}$ p105 \\ and p65 were examined. A total of 16 mice met the inclusion criteria. A \\ significant increase in the number of Kupffer cells $(\mathrm{p}<0.001)$ and NF- $\kappa B$ \\ p105 $(\mathrm{p}=0.001)$ was observed after administration of probiotic. No \\ significant differences were observed in NF-kB p65 ( $p=0.236)$. \\ Administration of probiotics affects the innate immune response (NF- $\kappa B$ \\ p105 and Kupffer cell) in the liver tissue but not in NF- $\mathrm{kB}$ p65.
}

\section{Introduction}

In Indonesia, the prevalence of liver disease in children is still relatively high, although the actual prevalence is still unknown (Hadi, 2000). The incidence of liver disease in infants is 1 from 2,500 live births with atresia biliary, metabolic abnormalities, and neonatal hepatitis. Thus, older children experience metabolic disorder, intrahepatic chronic cholestasis, and obesity-related steatohepatitis (Arya and Balistreri, 2002).

Microflora in the gastrointestinal tract has an important role in hepatocyte cell function (Gratz et al., 2010; Iacono et al., 2011; Jonkers and Stockbrügger, 2007). A symbiotic relationship exists between the liver and the digestive tract, known as the gut-liver axis (Imani Fooladi et al., 2013; Jonkers and Stockbrügger, 2007). The functional relationship between the intestines with the liver includes the balance of immunological responses (Imani Fooladi et al., 2013; Lata et al., 2011; Miyake and Yamamoto, 2013).

Probiotics is known to have a protection effect in the gastrointestinal tract and is explained through a variety of mechanisms (Boirivant and Strober, 2007; Pagnini et al., 2010; Yan and Polk, 2011). 
Probiotic effects in animal studies have demonstrated increasing innate immune response through enhancement of TLR-2, TLR4 , and transcription factors NF-kB p65 and p105 (Hegazy and El-Bedewy, 2010; Petrof et al., 2004; Yao et al., 2017).

The role of probiotics through epitope lipoteichoic acid will be captured by lipoteichoic-binding protein that will be recognized by TLR-2 and TLR-4 in dendritic cells, which migrate through the lymphatic tract. Dendritic cells will interact with Kupffer cells in the liver, therefore resulting in innate immune response (Boirivant and Strober, 2007; Thomas and Versalovic, n.d.; Trivedi and Adams, 2012; Yan and Polk, 2011).

Based on this idea, we studied the effects of probiotic to the innate immune response in the liver.

\section{Materials and methods}

This study used randomized posttest-only control group design conducted in Biochemistry Laboratories Universitas Airlangga, Surabaya, from February until May 2008. Ethical approval was issued by the Veterinary Faculty Research Ethical Committee with ethics certificate number 034-KE/ II/ 2008.

\subsection{Samples}

We used the animal study model obtained from Pusat Veterinaria Farma Surabaya. Sixteen Mus musculus (BALB/c) mice aged 10-12 weeks old, male, and approximately 30-40 gr were adopted for 1 week before starting treatment (Figure 1). The mice were divided into two groups: probiotic and placebo. The probiotic group was given multispecies probiotic for 21 days. The placebo group was given a placebo for 21 days via a gastric tube. Necropsy was performed on the probiotic and placebo groups on day 22. The liver was dissected for analysis.

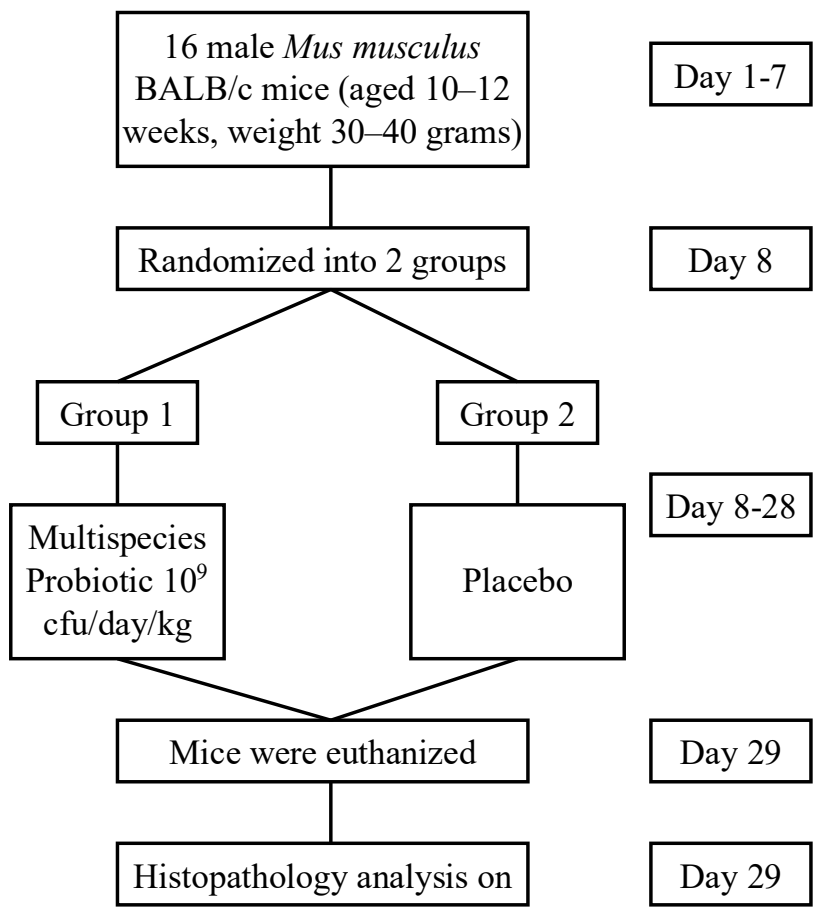

Figure 1. Animal treatment

\subsection{Probiotic}

The probiotic group used multispecies probiotic with composition Lactobacillus casei PXN 37, Lactobacillus rhamnosus PXN 54, Lactobacillus acidophilus PXN 35, Lactobacillus bulgaricus PXN 39, Bifidobacteria breve PXN 25, Bifidobacteria infantis PXN 27, Streptococcus thermophilis PXN 66, and fructooligosaccharide packed in an aluminum foil sachet. Probiotic was administrated by dissolving in $0.5 \mathrm{ml} \mathrm{D5 \%}$ and dose of $10^{9} \mathrm{cfu} / \mathrm{day} / \mathrm{kg}$ animal weight via a gastric tube once daily for 21 days.

\subsection{Immunohistochemistry}

The liver section was cleaned in a $10 \%$ formalin buffer solution, followed by dehydration, clearing, impregnating, and embedding. Immunohistochemistry was performed to determine the innate immune response. The liver section was probed with NF- $\mathrm{BB}$ p65 monoclonal antibody (33-9900; Thermo Fisher Scientific, Waltham, MA, USA) and p105 monoclonal antibody (GTX60465; GeneTex Inc., Irvine, CA, USA). The Kupffer cell was probed with CD68 monoclonal antibody. Number of Kupffer 
cells and cells which expressing NF- $\mathrm{KB}$ p65 and p105 were counted the mean number of cells within 20 random fields under a light microscope (CX21; Olympus, Tokyo, Japan) at 1000x magnification.

\subsection{Statistical analysis}

Data were analyzed using SPSS version 22 software. Descriptive analysis was conducted to determine the immune response profile in each group and difference in profile changes from the probiotic and control groups. Differences between groups were analyzed by the t-test for variables that were normally distributed and the Mann-Whitney test for variables that were not normally distributed.

\section{Results and discussions}

A total of 16 mice were included in this study, all of which were male. They were divided into two groups. The characteristics of the subject are described in Table 1.

A significant difference was observed between the Kupffer cell count and NF- $\mathrm{KB}$ p105 in the probiotic group compared with the control group. By contrast, no significant difference was observed between NF- $\mathrm{NB}$ p65 in the probiotic group and that in the control group, as shown in Table 2. The liver section that had been stained with immunohistochemistry, which showed number of Kupffer cells and Kupffer cells that expressed NF- $\kappa \mathrm{B}$ p 105 and NF- $\kappa \mathrm{B}$ p 65 in mice is shown at the figure 2, figure 3 and figure 4 . Innate immune response in the liver is a defense mechanism because it is a physical barrier and stimulates the adaptive immune system. The Kupffer cell is the main macrophage in the liver and plays an important role in normal physiology and homeostasis. It participates in the acute and chronic response in the liver with toxic substances and acts as a liver protector (Roberts et al., 2006).

Innate immune response activation also stimulates the Kupffer cell to produce hepatoprotective cytokine, IL-6, and IL-10 during alcoholic liver disease and express TLRs and main cytokine producer pro- and antiinflammation (Gao, 2012; Szabo et al., 2007).
Similar to a previous study by Neuman using the probiotic Lactobacillus acidophilus UFV$\mathrm{H} 2 \mathrm{~b} 20$, this Lactobacillus acidophilus can survive in stressful conditions in the gut. Furthermore, the probiotic group had two times more Kupffer cells that are responsible for bacterial clearance and can stimulate nonspecific immune response (Neumann et al., 1998).

Corbitt et al. (2013), in their study, showed a strong correlation between probiotic with the Kupffer cell maturation status and its function. Gut bacteria will release unique composition microbe-associated molecular patterns in the circulation, which can upregulate LSEC ICAMI expression, that influence the number and function of Kupffer cells in the liver.

Giving probiotic in mice significantly increased NF- $\kappa \mathrm{B}$ p105 compared with the control group. Miyoshi et al. (2001), studied three rats as cholestasis animal models showing that NF- $\kappa \mathrm{B}$ is activated in the hepatocyte. The $\mathrm{NF}-\kappa \mathrm{B}$ activation function decreases hepatocyte apoptosis and liver damage. The ability of bile acids to become potentially toxic in activating $\mathrm{NF}-\kappa \mathrm{B}$ might cause pathological adaptation that helps survival and continues the hepatocyte function.

The NF- $\kappa \mathrm{B}$ function bridges the innate immune system and the adaptive immune system by releasing an inflammatory mediator (Luedde and Schwabe, 2012; Seki and Schnabl, 2012).

However, no significant difference in NF$\kappa \mathrm{B}$ p65 was observed between the treatment and the control group. This result was caused by the fact that the animal models in this study were a healthy sample not found in the inflammation model. Proteolysis NF- $\kappa \mathrm{B}$ p 105 becomes NF- $\kappa \mathrm{B}$ p65, and NF- $\kappa \mathrm{B}$ p50 is triggered by inflammation (Baud and Derudder, 2011; Oeckinghaus and Ghosh, 2009). 

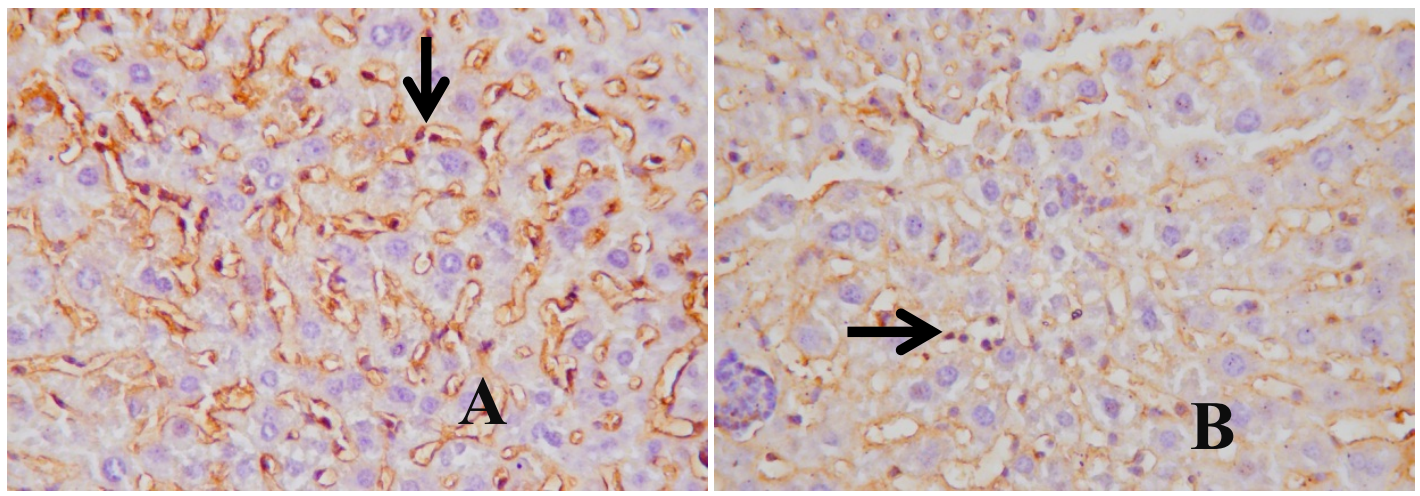

Figure 2. The liver section stained with immunohistochemistry method with monoclonal antibody anti mouse CD68 with 1000x magnification. The arrows pointed the Kupffer cells with expressed CD68 as the antibody marker for Kupffer cells.

\section{A. Probiotic group; B. Control group.}
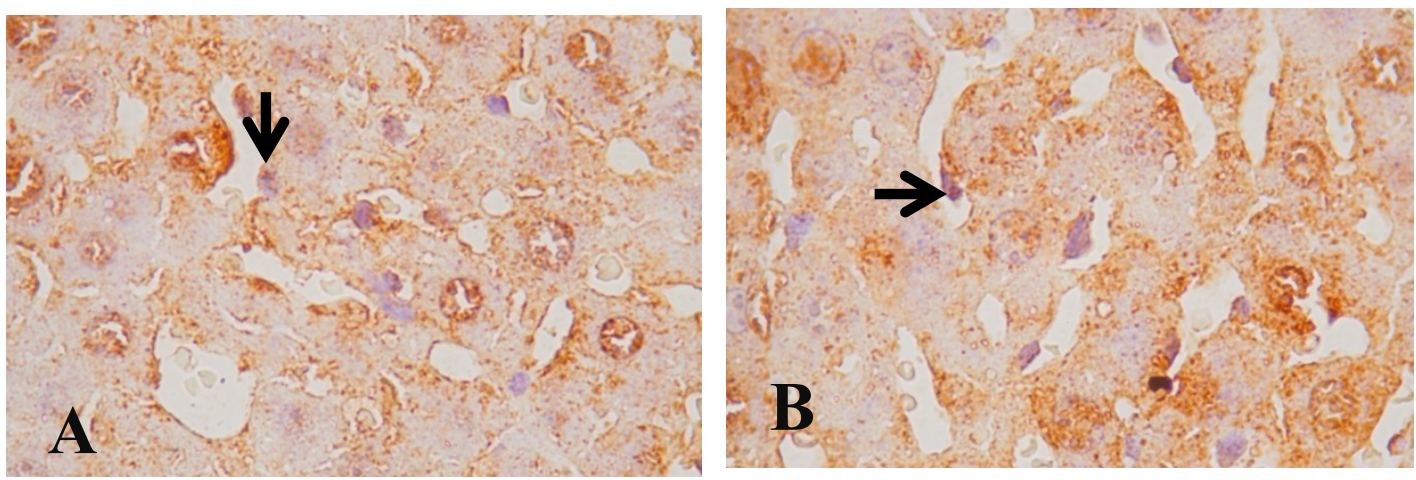

Figure 3. The liver section stained with immunohistochemistry method with monoclonal antibody anti mouse NF-kB p105 with 1000x magnification. The arrows pointed the Kupffer cells with expressed NF-kB p105 as the antibody marker for Kupffer cells.

A. Probiotic group; B. Control group
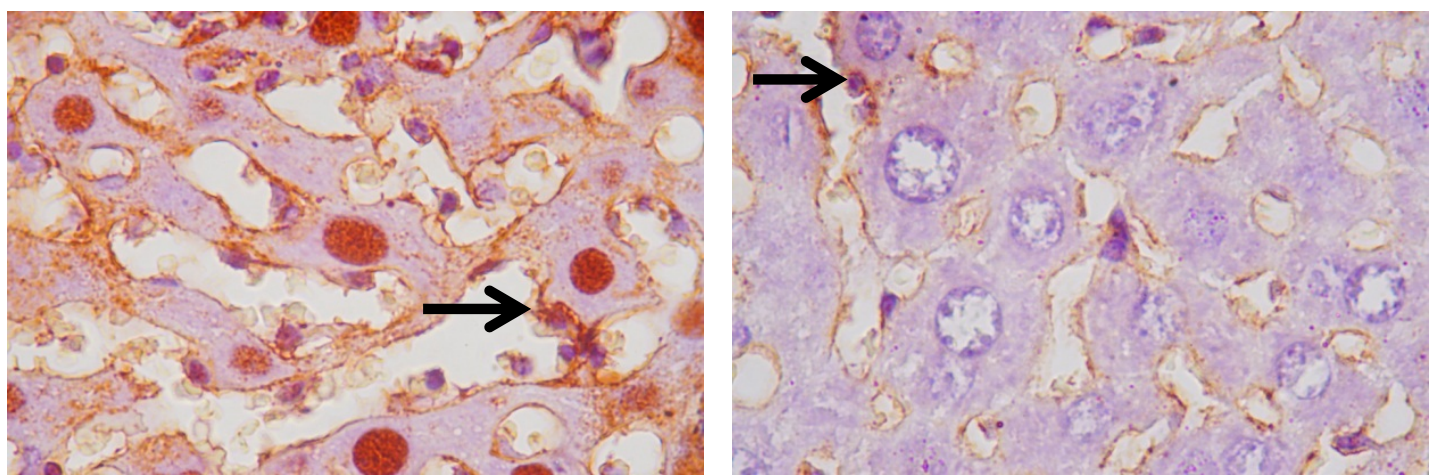

Figure 4. The liver section stained with immunohistochemistry method with monoclonal antibody anti mouse NF-kB p65 with 1000x magnification. The arrows pointed the Kupffer cells with expressed NF-kB p65 as the antibody marker for Kupffer cells.
A. Probiotic group; B. Control group. 
This result did not agree with previous studies on the gut due to the difference in organ and immune response. Moreover, probiotic was administrated through the gastrointestinal tract, so the stronger immune response occurred in the gut and the weaker immune response occurred in the liver (Darma et al., 2009; Trivedi and Adams, 2016).Previous studies showed that giving the probiotic group with LPS increased TLR-2 and TLR-4 activation and NF- $\kappa$ B p50 and p65 activation. Administration of probiotic decreased TLR-2 expression and NF- $\kappa$ B p50 activation caused by LPS, which was expected to decrease the inflammation reaction (Luh Putu HM et al., 2011).

Expressing the protein NF- $\kappa \mathrm{B}$ can give specificity in responding to some stimulus. NF$\kappa \mathrm{B}$ p50 and p65 play an important role in IL-6 production in synovial fibroblast and are closely involved in inflammation gene activation with IL-1 or TNF- $\alpha$ in human monocytes (Seki and Schnabl, 2012). However, inhibition of NF-кB can reduce the viability of hepatocytes besides beneficial results (Luedde and Schwabe, 2012).

$\mathrm{Xu}$ et al. (2011), in his animal model research, suggested administration of probiotic as a safe and cheap therapy for nonalcoholic fatty liver disease because oral probiotic supplementation has been proven to decrease liver fat accumulation.

This study has limitations because mice were used, although mice share many similarities with humans in the immunologic aspect (Mestas and Hughes, 2004) and need pathogen as an inflammation inducer. Further studies are needed to describe the probiotic mechanism in the immunological aspect.

\section{Conclusions}

Administration of probiotic influences the innate immune response in the liver with increasing Kupffer cells and number of Kupffer cells that express NF- $\kappa \mathrm{B}$ p105 in mice. However, no influence was observed in the number of Kupffer cells that express NF- $\mathrm{B}$ p65 in mice.

\section{References}

Arya, G., \& Balistreri, W. F. (2002). Pediatric liver disease in the United States: Epidemiology and impact. Journal of Gastroenterology and Hepatology, 17(5), 521-5.

Baud, V., \& Derudder, E. (2011). Control of NF$\kappa \mathrm{B}$ activity by proteolysis. Current Topics in Microbiology and Immunology, 349, 97-114. DOI: $10.1007 / 822010101$.

Boirivant, M., \& Strober, W. (2007). The mechanism of action of probiotics. Current Opinion in Gastroenterology, 23(6), 679-92. DOI: 10.1097/MOG.0b013e3282f0cffc.

Corbitt, N., Kimura, S., Isse, K., et al. (2013). Gut bacteria drive Kupffer cell expansion via MAMP-mediated ICAM-1 induction on sinusoidal endothelium and influence preservation-reperfusion injury after orthotopic liver transplantation. American Journal of Pathology, 182(1). American Society for Investigative Pathology, 180 191. DOI: 10.1016/j.ajpath.2012.09.010.

Darma, A., Sudarmo, M., Ranuh, R., et al. (2009). Pengaruh probiotik terhadap kesigapan respon imun innate mukosa dalam menghadapi pajanan patogen. Airlangga.

Gao, B. (2012). Hepatoprotective and antiinflammatory cytokines in alcoholic liver disease. Journal of Gastroenterology and Hepatology, 27, 89-93. DOI: 10.1111/j.1440-1746.2011.07003.x.

Gratz, S. W., Mykkanen, H., \& El-Nezami, H. S. (2010). Probiotics and gut health: A special focus on liver diseases. World Journal of Gastroenterology, 16(4), 403-10.

Hadi, S. (2000). Diagnosis ultrasonik pada sirosis hati. Hepatologi. Jakarta: Mandar Maju.

Hegazy, S. K., \& El-Bedewy, M. M. (2010). Effect of probiotics on pro-inflammatory cytokines and NF-kappaB activation in ulcerative colitis. World Journal of Gastroenterology, 16(33), 4145-51.

Iacono, A., Raso, G. M., Canani, R. B., et al. 
(2011). Probiotics as an emerging therapeutic strategy to treat NAFLD: Focus on molecular and biochemical mechanisms. Journal of Nutritional Biochemistry, 22(8), 699-711.

DOI: $10.1016 /$ j.jnutbio.2010.10.002.

Imani Fooladi, A. A., Mahmoodzadeh Hosseini, H., Nourani, M. R., et al. (2013). Probiotic as a novel treatment strategy against liver disease. Hepatitis Monthly, 13(2), e7521. DOI: $10.5812 /$ hepatmon. 7521.

Jonkers, D., \& Stockbrügger, R. (2007). Review article: Probiotics in gastrointestinal and liver diseases. Alimentary Pharmacology \& Therapeutics, 26 Suppl 2, 133-48. DOI: 10.1111/j.1365-2036.2007.03480.x.

Lata, J., Jurankova, J., Kopacova, M., et al. (2011). Probiotics in hepatology. World Journal of Gastroenterology, 17(24), 28906. DOI: 10.3748/wjg.v17.i24.2890.

Luedde, T., \& Schwabe, R. F. (2012). Carcinoma. $\quad 8(2), \quad 108-118 . \quad$ DOI: 10.1038/nrgastro.2010.213.

Luh Putu, H. M. N., Sumakto, S., \& Santoso, S. (2011). Probiotik menurunkan ekspresi TLR2 dan aktivasi NF-Kb p50 pada sel mononuklear darah mencit yang terpajan lipopolisakarida E. coli. Jurnal Kedokteran Brawijaya, 26(3), 136-144. DOI: 10.21776/ub.jkb.2011.026.03.11.

Mestas, J., \& Hughes, C. C. W. (2004). Of mice and not men: Differences between mouse and human immunology. Journal of Immunology (Baltimore, Md.: 1950), 172(5), 2731-8.

Miyake, Y., \& Yamamoto, K. (2013). Role of gut microbiota in liver diseases. Hepatology Research: The Official Journal of the Japan Society of Hepatology, 43(2), 139-46. DOI: 10.1111/j.1872-034X.2012.01088.x.

Miyoshi, H., Rust, C., Guicciardi, M. E., et al. (2001). NF-kappaB is activated in cholestasis and functions to reduce liver injury. American Journal of Pathology, 158(3), 96775.

Neumann, E., Oliveira, M. A., Cabral, C. M., et al. (1998). Monoassociation with Lactobacillus acidophilus UFV-H2b20 stimulates the immune defense mechanisms of germfree mice. Brazilian Journal of
Medical and Biological Research $=$ Revista brasileira de pesquisas medicas e biologicas, 31(12), 1565-73.

Oeckinghaus, A., \& Ghosh, S. (2009). The NFB family of transcription factors and its regulation. Cold Spring Harbor Perspectives in Biology, 1(4), a000034-a000034. DOI: 10.1101/cshperspect.a000034.

Pagnini, C., Saeed, R., Bamias, G., et al. (2010). Probiotics promote gut health through stimulation of epithelial innate immunity. Proceedings of the National Academy of Sciences of the United States of America, 107(1), 454-9. DOI: 10.1073/pnas.0910307107.

Petrof, E. O., Kojima, K., Ropeleski, M. J., et al. (2004). Probiotics inhibit nuclear factor- $\mathrm{kB}$ and induce heat shock proteins in colonic epithelial cells through proteasome inhibition. Gastroenterology, 127(5), 1474 1487. DOI: 10.1053/j.gastro.2004.09.001.

Roberts, R. A., Ganey, P. E., Ju, C., et al. (2006). Role of the Kupffer cell in mediating hepatic toxicity and carcinogenesis. Toxicological Sciences, $\quad 96(1), \quad 2-15 . \quad$ DOI: 10.1093/toxsci/kfl173.

Seki, E., \& Schnabl, B. (2012). Role of innate immunity and the microbiota in liver fibrosis: Crosstalk between the liver and gut. 3, 447458. DOI: 10.1113/jphysiol.2011.219691.

Szabo, G., Mandrekar, P., \& Dolganiuc, A. (2007). Innate immune response and hepatic inflammation. Seminars in Liver Disease, 27(4), 339-350. DOI: $10.1055 / \mathrm{s}-2007-$ 991511.

Thomas, C. M., \& Versalovic, J. (n.d.). Probiotics-host communication: Modulation of signaling pathways in the intestine. Gut Microbes, 1(3), 148-63.

Trivedi, P. J., \& Adams, D. H. (2012). SelfTrivedi, P. and Adams, D. (2012). Selfassessment questions: The hepato-enteric immune axis in health and disease. Clinical Medicine, 12(6), pp.s79-s79.

\section{Acknowledgment}

The authors thank all the teams who worked on this study. 